\title{
Religious Power Struggle and Cembengan Tradition in Madukismo Sugar Factory Yogyakarta
}

\author{
Abdul Qodir Shaleh ${ }^{1, *}$, Saifudin Zuhri², Ilyya Muhsin ${ }^{3}$ \\ 1 STAI Sunan Pandanaran Yogyakarta, Indonesia; e-mail: ab405ha@gmail.com \\ 2 STIE SBI Yogyakarta, Indonesia, e-mail: saifudin_mf@yahoo.com \\ 3 IAIN Salatiga, Indonesia, e-mail: ilyya_muhsin@iainsalatiga.ac.id \\ * Correspondence
}

Received: 2020-03-27; Accepted: 2020-05-27; Published: 2020-05-30

\begin{abstract}
As an entity famous for its mystical synthesis, Yogyakarta Palace can harmonize between mysticism and religious and social expressions. This is represented in, one of them, Madukismo Sugar Factory in Yogyakarta, a sugarcane processing factory owned by Yogyakarta Palace. In its processing, there is one of local wisdom that reflects the existence of this mystical synthesis, namely Cembengan tradition. From it, arises a power struggle between orthodoxy and heterodoxy, bearing in mind that this factory is a public company which naturally comes from various religious groups. The main problems: how Cembengan tradition in Madukismo Sugar Factory in Yogyakarta is and how the struggle for religious power in Cembengan tradition is. This paper aims to find out Cembengan tradition and the struggle for the religious power that exists in the tradition. This study uses discursive action model as its approach. The research data were analyzed qualitatively using interview and literature study techniques. It was found that in Cembengan tradition, there is a tradition with a variety of activities, which is essentially asking for safety and blessing. The uniqueness is in the series of activities, there are istigotsah and pilgrimage to the tomb of the ancestor together, which is in series with the procession of Labuhan Laut, sugarcane bride and groom parade, and puppet show. This certainly gives rise to a power struggle between orthodoxy and heterodoxy, bearing in mind that Yogyakarta itself is the orthodox Islamic base as well as strong heterodoxy bases. However, Cembengan tradition continues because there are various things that are proven to occur and determine the quality of works and production results from Madukismo Sugar Factory itself. We can conclude that no matter how strong the struggle is, the mystical synthesis is still ongoing.
\end{abstract}

Keywords: Cembengan Traditio; Madukismo Sugar Factory; Mystical Synthesis; and Power Struggle.

Abstrak: Sebagai entitas yang terkenal dengan sintesis mistiknya, Keraton Yogyakarta mampu
mengharmonisasikan antara kemistikan dengan ekspresi keberagamaan dan kemasyarakatan. Hal ini
dapat dilihat salah satunya dalam Pabrik Gula Madukismo di Yogyakarta, sebuah pabrik pengolahan
tebu yang dimiliki oleh Keraton Yogyakarta. Dalam proses pengolahannya, terdapat salah satu local
wisdom yang mencerminkan adanya sintesa mistik tersebut, yaitu tradisi Cembengan. Dari sinilah
muncul pertarungan kuasa antara ortodoksi dan heterodoksi, mengingat pabrik ini adalah
perusahaan terbuka yang tentu saja berasal dari berbagai kelompok keagamaan. Pokok persoalannya
adalah bagaimana sebenarnya tradisi Cembengan di PG Madukismo Yogyakarta tersebut?
Bagaimana pertarungan kuasa keberagamaan dalam tradisi Cembengan tersebut? Tujuan paper ini
adalah untuk mengetahui tradisi Cembengan dan pertarungan kuasa keberagamaan yang ada di
dalam tradisi tersebut. Untuk alat analisisnya, penelitian ini menggunakan model discursive action
yang diperkenalkan oleh Potter. Data penelitian dianalisis secara kualitatif dengan menggunakan
teknik wawancara dan studi pustaka. Hasilnya adalah bahwa dalam tradisi Cembengan terdapat
tradisi dengan berbagai rangkaian kegiatan, yang intinya adalah memohon keselamatan dan
keberkahan. Uniknya, dalam rangkaian kegiatan tersebut, ada istigotsah dan ziarah ke makam
leluhur bersama, yang berangkaian dengan prosesi labuhan laut, kirab manten tebu, dan pegelaran 
wayang. Hal ini tentu memunculkan pertarungan kuasa antara ortodoksi dan heterodoksi, mengingat Yogyakarta sendiri adalah basis Islam ortodoks dan sekaligus basis heterodoksi yang kuat. Namun, tradisi Cembengan tetap berlangsung, karena adanya berbagai hal yang terbukti terjadi dan menentukan kualitas kerja dan hasil produksi dari PG Madukismo itu sendiri. Dari hal ini, dapat disimpulkan bahwa seberapapun kuatnya pertarungan tersebut, sintesis mistik itu tetap berlangsung.

Kata Kunci: Tradisi Cembengan; PG Madukismo; Sintesis Mistik; and Pertarungan kuasa.

\section{Introduction}

In interpreting the pattern of Javanese religious life, Ricklefs mentions that there is a mystical synthesis that occurs. There are three main pillars; they are: first, a strong Islamic awareness, where being a Javanese means being a Muslim; second, the implementation of the five pillars of ritual in Islam, namely shahada, prayer, zakat, fasting, and hajj; and third, acceptance of the reality of Javanese spiritual powers such as Nyi Roro Kidul, Sunan Lawu, and many more supernatural beings (Ricklefs, 2008, p. 34).

This mystical synthesis has been practiced since the days of Sultan Agung, the famous Sultan of Mataram, who could compromise between Islamic and mystical lives. Sultan Agung has mystical works that have highly Islamic substance such as Serat Sastra Gendhing, Kitab Nitisastra and Serat Pangracutan (Partini, 2010, p. 22). Sultan Agung also wrote Javanese history, chronicles, and the construction of tombs on the hill.G Moedjanto, Konsep Kekuasaan Jawa: Penerapannya Oleh Raja-Raja Mataram (Yogyakarta: Kanisius, 1987), 157. In terms of Javanese history, Sultan Agung transformed the Indian-style Old Javanese Saka calendar system with a hybrid Javanese system based on Hijri (Ricklefs, 2013, p. 32). Sultan Agung also encouraged the process of Islamization of Javanese culture (Partini, 2010, p. 23), thus making the cultural life of the people of Mataram more Islamic. However, he still did not break his mystical relationship with the supreme non-Islamic ruler, Ratu Kidul or Nyi Roro Kidul, exactly as stated by Ricklefs (Ricklefs, 2013).

What Sultan Agung did with this mystical synthesis reflects the balance of contestation between heterodoxy and orthodoxy. This contestation continues to color the journey of Mataram's royal power. There is a period of ups and downs between the two relations. Sometimes, the heterodox is at the top, but at other times the orthodox dominates. This continued to happen even when Mataram was split in two due to Giyanti agreement (Ricklefs, 1998, pp. 148-150). These areas are Yogyakarta and Surakarta Sultanates.

The Sultanate of Yogyakarta has been applying the mystical synthesis to date. The mystical synthesis is often applied to various traditions, which show the expression of Javanese people's patterns and identities in life with various dynamics with economic, political, social, cultural, and, of course, religious diversity dimensions. Even, it is greatly influenced by their interactions with the outside world (Ricklefs, 2013, pp. 43-57).

One of the expressions is implemented in the economic-cultural aspect, namely the preserving of Cembengan tradition in Madukismo Sugar Factory (PG) Yogyakarta. This factory is a Limited Liability Company where most of its shares are owned by Sri Sultan Hamengkubuwono, the ruler of the Sultanate of Yogyakarta. As a public company, of course, its management is open and various groups are involved. In a religious context, there are many groups of people in this company, not only of Islam, but also of other religions. Even, the religiosity of Islam involves many expressions, from the puritans to the abangan (Muslim Javanese). From this condition, there is a possibility of contestation between the orthodox and heterodox groups related to Cembengan tradition in this sugar factory.

Therefore, the problems raised in this paper are how Cembengan tradition at Madukismo Sugar Factory in Yogyakarta is? And how the struggle for religious power in Cembengan tradition is? From these problems, the researcher aims to find out how Cembengan tradition is carried out to bring up the contestation between the orthodoxy and heterodoxy. In addition, the most important thing is whether 
with this contestation, the mystical synthesis will lose its spirit or even on the contrary, it will remain sustainable.

Basically, the power struggle between orthodoxy and heterodoxy at Madukismo Sugar Factory has not yet been studied. The study of Cembengan is usually centered on the meaning of symbol (Rosanawati, 2018), tradition (Pontjowolo \& Darmawan, 1995), tourism (Pradana, 2018) and function of Cembengan (Wulandari, 2009). While the struggle between orthodoxy (Alimahtusadiyah, 2015) and heterodoxy is also widely studied, but no one discusses it in the Cembengan tradition nor in PG Madukismo. Therefore, this paper have novelty as a scientific inquiry.

The existence of Cembengan Tradition in Madukismo Sugar Factory is a symbolic discourse of mystical synthesis in the lives of Javanese people in Yogyakarta. This is certainly a reflection of what is practiced by Yogyakarta Palace, which still provides an open space for the existence of this mystical synthesis.

On the other hand, Yogyakarta is the basis of orthodox Islam, where the Muhammadiyah organization is based here (Nakamura, 2012). In addition, fundamentalist and radicalist Islamic movements also grow and develop in Yogyakarta, i.e Salafi Movement (Hasan, 2006, 2009), Hizbut Tahrir Indonesia (HTI) (Junaedi, 2012), Islamic Ummah Forum (FUI) (Ahnaf, 2016), and so on. Therefore, heterodox religious practices will naturally find strong challenges and oppositions from the Islamic orthodox group, albeit in a varied arena.

In this respect, it would be very interesting to see this contestation between the orthodoxy and heterodoxy in Cembengan tradition at Madukismo Sugar Factory. Cembengan tradition is a symbol of the practice of mystical synthesis which is still held by Yogyakarta Palace through Madukismo Sugar Factory.

From this explanation, Cembengan tradition is a symbolic discourse that shows the existence of a discursive act in it. Cembengan discursive action is an event which is then discussed as part of a method to explore the meaning of cause and effect behind an event. Language needs theoretical significant meaning as a medium of cause and effect thinking. Therefore, this is where the significance of discursive actions is used to investigate the everyday cause-and-effect attribution that manifests in social actions (Edwards \& Potter, 1993).

Thus, a discursive social action always has an interconnected meaning that can encourage the creation of an understanding of the context described in the action. This is what happens in Cembengan tradition at Madukismo Sugar Factory in Yogyakarta, which is a performance of traditions based on local wisdom but brings certain discursive powers that will give birth to discourses capable of influencing the object to which it is intended.

The research on discursive actions is based on actions rather than recognition or behavior. A very clear action is carried out through discourse, traditional psychological concepts (memory, attribution, categorization, etc.) which are conceptualized in discursive terms. The actions are carried out in the form of discourse which is entirely situated in a broad set of activities from various types of events (Potter et al., 1993). This is clearly illustrated in a series of Cembengan tradition activities in Madukismo Sugar Factory in Yogyakarta.

From the theoretical domain, Cembengan tradition shows the symbolic discourse of the mystical synthesis, which confirms the heterodoxy of Islamic religiosity in Madukismo Sugar Factory. For this reason, when there is a rejection of this tradition from orthodox Muslims, it will certainly lead to contestation between the two groups. However, the tradition still finds its own place, especially in Javanese society.

Activities, such as tosan aji, jamasan puasa keraton, ruwatan, and bersih desa, are proved to be enthusiastically followed by one of the elements of Javanese society in the Mataraman subculture. The most expressive thing is the commemoration of Javanese New Year, the first of Suro, which gets a big attention in the Mataraman subculture area. At the same time, the Islamic New Year, which coincides with the Javanese New Year, is celebrated in Islam by all puritan Muslims, so the nuances of the competition are felt during that day. Newspapers, especially those published in Solo and Yogyakarta, massively expose Javanese Suronan activities. Even Harian Kedaulatan Rakyat, since 2001, has made 
the full-page rubric of Mekar Sari every Thursday, which contains Javanese activities mainly containing Javanese mysticism, sacralization, and mythology (Wahyono, 2001). From this description, of course, the nuances of contestation between the orthodoxy and heterodoxy in Javanese society are very clear.

The discourse of mystical synthesis developed in Cembengan tradition is so strongly raised, which is certainly manifested in the form of actions that further strengthen the nuances of the contestation. Moreover, a discourse will certainly never be neutral in various aspects of human life. Even, it originates from natural assumptions. Basically, a discourse is deliberately shaped and conditioned by institutions that are more dominant over the aspects they dominate. Hence, according to Foucault, a discourse is a political commodity, a phenomenon of limitations, prohibition, and exclusion.

Thus, when Yogyakarta Palace preserves Cembengan tradition at Madukismo Sugar Factory, there is a power that represents the institution of the palace in the activities of Madukismo Sugar Factory. This is one aspect of reinforcement of why Cembengan tradition continues to be sustainable amid the movements and challenges of an increasingly changing era. Moreover, this tradition is believed to provide its own "strength" for the growth and development of Madukismo Sugar Factory.

To elaborate the religious power struggle through Cembengan tradition at Madukismo Sugar Factory in Yogyakarta, a qualitative study was conducted. The data sources were traced bibliographically and with fieldwork using a sociological approach. In this case, the researcher examines various books, articles, research reports, various academic studies, and a variety of relevant documentation and media, mainly related to Cembengan tradition and its various discursive actions.

The main data source is, of course, through empirical observations of Cembengan Tradition at Madukismo Sugar Factory. In addition, the main source of this research is the interview with the informants who are directly related to the research problems. However, because the object of this paper is not a fixed social fact, which can still change in the action process and may even be temporary and also only in the form of discursive action, this research will certainly have its own limitations and may have an element of subjectivity in its interpretation. The dynamic social phenomena contained in the object of this paper do not become an obstacle for the study, bearing in mind that there is a general pattern that has its own uniqueness from each actor involved.

The main reference in this research is the context that occurs in the field associated with observations and direct interviews with actors associated with the object of this research, namely primary and secondary informants from Cembengan Tradition. The technique of determining the informants is centered at the research locus, considering that most of the informants are in Madukismo Sugar Factory. The author tried to get along the informants naturally, so the information sought can be obtained naturally and as it is in accordance to the purpose of this research.

This paper also relies on the documentation technique. Documentation is a way to obtain data by analyzing the factors that are arranged logically from written and unwritten documents that contain certain clues. These documents take the form of written sources in the form of literature, previous research, and others relevant to this research.

This paper is centered at Madukismo Sugar Factory in Yogyakarta. The data analysis had been carried out since the data collection in the field, so when the researcher collected the data in the field, it was immediately followed by the activities of writing, categorizing, classifying, reducing, analyzing, and interpreting into the context of all research problems.

In analyzing the data, the researcher did the follow steps: data categorization and codification, data reduction, data display and classification, and verification and conclusions. Categorization and codification of data is a process of categorizing and codifying the data obtained in the field. Data reduction is the process of selecting, sorting, focusing attention, simplifying, abstracting and transforming raw data from written field notes. Data display is the process of presenting a set of information in the form of narrative text and other presentation models that might be used. The directions of the presentation of the data are simplification, study, sequencing, and grouping of information that is complex, scattered, and less meaningful into a unified form that is understandable and meaningful. Verification or conclusion drawing means trying to understand and make meaning of 
facts, phenomena, configuration patterns that produce conclusions, propositions, and theories as research findings and suggestions for further research.

\section{Result and Discussion}

The religious power struggle between the orthodoxy and heterodoxy certainly must begin by tracing Cembengan tradition itself. According to Sri Hartono (Personal Communication, July 1, 2019), the staff of Madukismo Sugar Factory on the plant and raw material supply department as well as the Cembengan committee of Madukismo Sugar Factory, Cembengan tradition essentially means a selamatan (communal feast) in order to avoid sengkolo (threats). Cembengan itself comes from the Chinese language, Cing Bing, which is a tradition of the Chinese community. This originated from the Chinese workers of Madukismo Sugar Factory who carried out the tradition which was intended for the safety in the process of sugarcane milling into sugar. This tradition was then inherited by the Javanese people in the sugar factory. However, because the Javanese tongue is unfamiliar with Chinese dialects, Cing Bing tradition was changed to Ceng Beng in Javanese dialect. This dialect then changed into Cembengan which is interpreted as a procession of Ceng Beng, just like other loan words, which means a procession, such as tahlil to be tahlilan and Surah Yasin to be yasinan.

This tradition has been running for decades and is still running to date. It aims to ask for blessings from the ancestors for the smooth running of the sugarcane milling in Madukismo Factory. Madukismo Sugar Factory and the surrounding community work together to hold a series of traditional ceremonies.

In this case, Cembengan tradition becomes part of Madukismo Sugar Factory, so the Company gives a structural legitimacy to the implementation of this tradition. Its implementation was decided through the Decree of the Director and General Manager of Madukismo Sugar Factory by establishing a structural committee. The committee is made up of Madukismo Sugar Factory employees who take turns each year. This committee is formed before the milling season around April. Not only is the committee formed, according to Fauzi from HRD staff (Fauzi, Personal Communication, March 14, 2019) but Madukismo Sugar Factory also provides human resources, finance, and facilitiesinfrastructure (places, equipment, transportation and communication, and so on).

According to Haryanto (Personal Communication, August 28, 2019) the head of the fabrication division at Madukismo Sugar Factory, Cembengan procession is always carried out by the elders and employees of Madukismo Sugar Factory. There are some processes to do. The first is the preparation for forming a committee. The second is determining the schedule or rundown of the event according to Javanese calculations. Then, Cembengan procession begins with the "ancak-ancak buang" ceremony, which is a procession of placing nearly 60 offerings at each factory station or strategic places at the factory and its surroundings as a sign of kulonuwun (asking permission) to earth guardians that they will begin a big celebration large, i.e. sugarcane milling. In the process of ancak-ancak buang, people pray to God as their gratitude for the last year's results and hoping that the next results will be more or at least the same. Then, people perform selamatan labuhan on Parangkusumo beach and pilgrimage to the tombs of ancestors, such as the tombs of the Kings of Mataram in Imogiri, the Tomb of Kota Gede, the Tomb of Majapahit Purbocolo, and the tomb of the elders who served the factory after performing istigotsah. After that, they visit or anjang sana the figures or those who are considered meritorious at the factory (pensioners who are considered seniors) to ask for their blessings and suggestions. The seventh step is helping the surrounding community or giving alms. After that, sports activities and arts performances are conducted for the surrounding community. Then, the sugarcane bride and groom parade is held as the main event of Cembengan. This begins by selecting sugarcane bride and groom on the field to be harvested. The groom usually comes from Kulonprogo or Purworejo while the bride is from Bantul. This bride gets a special ritual from Madukismo Sugar Factory. The sugarcane bride and groom are then paraded. It is the beginning of the milling. Lastly, a shadow puppet show is held in the Madukismo Sugar Factory area.

From the series of processions in Cembengan tradition, Madukismo employees have a very strong belief. First, psychologically, Cembengan makes the employees more peaceful, calm, and comfortable. With such mental conditions, they will work more thoroughly, discipline, passionately, and compactly. 
Thus, work disasters in the form of work accidents can be avoided. Second, with the implementation of Cembengan, the condition of the machine becomes more well maintained because machine maintainers and users are more thorough, calm, and careful in the use of these tools. Third, with the existence of a series of Cembengan, raw materials in the form of sugarcane plants become more abundant because since the planting process uses an approach that is in harmony with the nature, the problems of pests (rats) to the raw material can be overcome with local wisdom, namely eradication by spreading offerings in the sugarcane field. Fourth, there will be many disasters if they do not perform Cembengan, such as the results of sugar not as expected, the machine often turned off suddenly mysteriously, employee work accidents, and so on.

From the series of procession of Cembengan and various beliefs on this tradition that emerge, the symbolic discourse of the heterodoxy practice of religiosity is very strong. This is what is then challenged by the orthodox in Madukismo Sugar Factory. When Madukismo Sugar Factory was led by someone from a puritan religious community, the series of events of that were considered as shirks were eliminated. As a result, there was a tremendous opposition from the Madukismo community. Even, according to Ishariyanto, the staff employee in the plant/raw material department of Madukismo Sugar Factory (Ishariyanto, Personal Communication, September 5, 2019) the process of sugarcane milling after the removal of a series of events considered shirks was not optimal and did not produce the desired sugar. Also, the sugarcane machine did not run normally, thus affecting the quality and quantity of the yield. From this incident, the GM was then blamed. Finally, in the following year, the complete Cembengan procession was carried out.

From this, it is very clear that there is a power struggle there, but the power of the traditions based on local wisdom is more dominant. Moreover, Madukismo Sugar Factory is a company whose shares are mostly owned by Sri Sultan Hamengkubuwono. Sultan of Yogyakarta Palace, heir to the mystical synthesis tradition since the time of the Sultanate of Mataram. The dominance of heterodox is strengthened by the strong discourse behind Cembengan tradition.

There are several discourses that can be analyzed from Cembengan tradition, which is recognized by the HR staff of Madukismo Sugar Factory, Fauzi (Personal Communication, March 14, 2019). First, Cembengan can maintain a company culture based on tradition, increase productivity, create comfort of the work environment, and crate management stability. Second, Cembengan can motivate employee work spirit, create team cohesiveness and solidity, maintain harmony among employees, create a sense of employee peace, and increase employee loyalty. Third, Cembengan can also be a means of empowering the community both economically and socio-culturally, becoming part of corporate social responsibility, and utilization of cultural and social capitals. From these discourses, of course there is a strong domination of the heterodox group to preserve this tradition.

Not only that, this tradition can provide a balance for nature based on local wisdom. There is a harmony that can be created from this tradition between the activities of human life and the nature, especially in the process of planting/raw materials. According to Sri Hartono, the employee of the plant department that is related to the nature every day, sugarcane is God's creation. It means that as the same creatures of God, we need to greet it as well as possible. According to him, sugarcane can have good quality if there are foremen's footprints in the field. It means that they must pay a visit and talk to the sugarcane like they do to fellow human beings; for example: "Hai Tebu, kowe kurang opo dino iki? Air, pupuk, banyak rumput atau apa? (Hi Sugarcane, what do you need today? Water, fertilizer, lots of grass or something?)." Thus, there is an inner connection between the farmer, foreman, and sugarcane. Because, after all, sugarcane has become a means to earn living, it should be treated properly.

Specifically, Sri Hartono stated that in Cembengan procession, sugarcane planting begins with making offerings placed on the field to be planted as a symbol of asking permission to the earth because they want to plant before the tractor arrives. During the harvesting season, the same thing is done in order to ask permission to harvest. All of these are in the hope of getting good yields, not being attacked by pests, and so on. This certainly shows a harmony with nature.

Sri Hartono even explained that in dealing with pests, they are treated in harmony. In this case, pests are viewed positively. Even if there are pests, they beg that they still get a share. The most feared 
pest is the rat. Rats can eat from planting to harvest. Rats are not eradicated with pesticide because if pesticide is used, they will attack more blindly. In other words, rats will become more vengeful and angrier that they can attack the plants even worse. Because of that, they respond wisely. Only with the offerings, they believe that it will be more effective.

In addition, according to Haryanto, from the manufacturing department of Madukismo Sugar Factory, Cembengan can provide solutions for harmony among employees. According to Ishariyanto, Cembengan is very beneficial for employee performance. The logic is that by conducting Cembengan, employees feel calmer at work. With a calm and peaceful state of mind, they become more concentrated, conscientious, and comfortable at work. If this tradition is not held, anxiety will emerge and even lead to disunity or disputes among the employees themselves. There is even an action of pada ting celemong (grumbling in the back). Thus, in addition to individual motivation, Cembengan also serves to tie harmony among employees because they are united by the same beliefs. What are beyond the discourse of Cembengan as a whole, as described above, they certainly do not make sense. However, the Cembengan tradition is truly meaningful to them, so they continue to carry out this tradition, even though the orthodox condemn it.

According to the orthodox, the tradition shows religious practices which are heretics and not appropriate such as procession of Labuhan Laut, sugarcane bride-groom parade, and puppet show. However, what is shown by the orthodox is responded negatively. It shows strong dominance of the symbolic discourse that emerges beyond the tradition. This also shows that the discourse of mystical synthesis in Cembengan tradition is so dominant in the mind of Madukismo society. This is certainly manifested in the form of actions, both in relation to nature, humans, and even God.

From this explanation, it clearly shows there is the power struggle between the orthodox and the heterodox at Madukismo Sugar Factory. However, with the discourse that develops in Cembengan tradition, the heterodoxy gains dominant power. Moreover, this is supported by Yogyakarta Palace institution beyond the symbolic discourse of mystical synthesis that is implemented from the tradition, exactly as stated by Foucault that a discourse is a political commodity, a phenomenon of limitations, prohibitions, and exclusions.Michel Foucault, Power/Knowledge: Selected Interviews \& Other Writings 1972-1977, ed. Colin Gordon (New York: Pantheon, 1980), 245. Therefore, although the orthodox opposes, which results in a power struggle, because of the strong power of discourse implemented in Cembengan tradition, they have no power to hold it. As a result, this tradition continues to exist and provides a unique spirit for the people in Madukismo Sugar Factory in Yogyakarta.

\section{Conclusions}

From the discussion above, Cembengan Tradition turns out to have the dominant discourse in the lives of the people in the Madukismo Sugar Factory environment. The power of discourse in this tradition turns out to provide implementation of the power of mystical synthesis in the lives of the people at Madukismo Sugar Factory. This, indeed, strengthens the power of the heterodox to preserve this tradition. Moreover, there emerge beliefs that prove a significant influence in the hearts of the employees and people of Madukismo. This happens internally and externally. Internally, this tradition will have a tremendous impact on the performance, motivation and enthusiasm of the employees. Externally, it can provide the balance of the nature based on local wisdom, a typical statement of the heterodox group in the Madukismo Sugar Factory community

\section{References}

Ahnaf, M. I. (2016). Tiga Jalan Islam Politik di Indonesia: Reformasi, Refolusi dan Revolusi. Wawasan: Jurnal Ilmiah Agama Dan Sosial Budaya. https://doi.org/10.15575/jw.v1i2.728

Alimahtusadiyah. (2015). Ortodoksi Versus Heterodoksi: Islam Dan Polarisasi Media Di Indonesia Menjelang Pilpres 2014. Right: Jurnal Agama Dan Hak Azazi Manusia, 4(2), 341-372.

Edwards, D., \& Potter, J. (1993). Language and causation: A discursive action model of description and attribution. Psychological Review, 100(1), 23-41. https://doi.org/10.1037/0033-295X.100.1.23

Foucault, M. (1980). Power/Knowledge: Selected Interviews \& other Writings 1972-1977 (C. Gordon (ed.)). Pantheon. 
Hasan, N. (2006). Laskar Jihad: Islam, Militancy, and the Quest for Identity in Post-New Order Indonesia. Cornell Southeast Asia Program.

Hasan, N. (2009). Ambivalent Doctrines and Conflicts in the Salafi Movement in Indonesia. In R. Meijer (Ed.), Global Salafism: Islam's New Religious Movement. Oxford University Press.

Junaedi, D. (2012). Bendera Hizbut Tahrir Indonesia Daerah Istimewa Yogyakarta: Kajian Konteks Sejarah, Konteks Budaya, dan Estetika Semiotis. Kawistara, 2(3), 264-275.

Moedjanto, G. (1987). Konsep Kekuasaan Jawa: Penerapannya Oleh Raja-Raja Mataram. Kanisius.

Nakamura, M. (2012). The Crescent Arises Over the Banyan Tree: A Study of the Muhammadiyah Movement in a Central Javanese Town. ISEAS.

Partini, B. (2010). Serat Sastra Gendhing: Warisan Spiritual Sultan Agung yang Berguna untuk Memandu Olah Pikir dan Olah Dzikir. Panji Pustaka.

Pontjowolo, \& Darmawan, H. (1995). Tradisi Slamatan Giling Cembengan. Rekso Pustaka Mangkunegaran.

Potter, J., Edwards, D., \& Wetherell, M. (1993). A model of discourse in action. American Behavioral Scientist, 36(3), 383-401.

Pradana, C. S. (2018). Makna Prosesi Upacara Adat Giling dan Suling di Pabrik Gula Madukismo Sebagai Atraksi Wisata Budaya. Jurnal Gama Societa, 2(2), 91-100.

Ricklefs, M. C. (1998). Sejarah Indonesia Modern. Gadjah Mada University Press.

Ricklefs, M. C. (2008). Religious Reform \& Polarization in Java. ISIM Review, 21(Spring), 34-35.

Ricklefs, M. C. (2013). Mengislamkan Jawa: Sejarah Islamisasi di Jawa dan Penentangnya dari 1930 Hingga Sekarang. Serambi.

Rosanawati, I. M. R. (2018). Makna Simbolis Upacara Mantenan Tebu pada Tradisi Cembengan di Tasikmadu. Widya Sari: Jurnal Ilmiah Pendidikan, Sejarah, Dan Sosial Budaya, 20(2), 11-18.

Wahyono, S. B. (2001). Kejawaan dan Keislaman: Suatu Pertarungan Identitas. Jurnal Ilmu Sosial Dan Ilmu Politik, $5(1), 41-59$.

Wulandari, P. (2009). Fungsi Tradisi Slametan Cembengan dalam Menciptakan Keteraturan Sosial: Studi Deskriptif pada PT Pabrik Gula Krebet Baru Bululawang Malang. University of Muhammadiyah Malang.

\section{Interview}

Fauzi, Personal Communication, March 14, 2019

Haryanto, Personal Communication, August 28, 2019

Ishariyanto, Personal Communication, September 5, 2019

Sri Hartanto, Personal Communication, July 1, 2019

(C) 2020 by the authors. Submitted for possible open access publication under the terms and conditions of the Creative Commons Attribution (CC BY SA) license (https://creativecommons.org/licenses/by-sa/3.0/). 